\title{
Assessment of postural sway in people living with HIVIAIDS
}

\author{
Avaliação da oscilação postural em pessoas vivendo com HIV/AIDS
}

Bruno José Frederico Pimenta1, Felipe Arruda Moura ${ }^{1}$, Camila Ramos dos Santos ${ }^{1}$, Raquel de Melo Martins ${ }^{1}$, Jefferson Rosa Cardoso², Inara Marques ${ }^{1}$

\begin{abstract}
Introduction: Motor changes are observed in people living with HIV/AIDS. These changes may be associated with the chronicity of infection, continued use of antiretroviral medication, and/ or the presence of comorbidities. Objective: The objective of the present study was to evaluate postural sway in people living with asymptomatic HIV/AIDS under treatment with highly active antiretroviral therapy. Methods: Twenty-seven subjects, recruited at an HIV referral center, aged between 30 and 40 years, participated in the study, divided into two groups: HIV group $(n=12)$ and non-HIV group $(n=15)$. The participants performed an experimental task, remaining on a force platform in a static position, in bipedal support and semi-tandem positions, in conditions with and without vision. Results: The results demonstrated that visual occlusion, when the bipedal base was adopted, generated significant differences in the area of oscillation and mean velocity in both groups. Differences were also observed in the area and mean velocity of both groups when the semi-tandem position was adopted without vision. When comparing the groups, it was possible to identify significant differences in the semi-tandem base with vision. Conclusion: Considering these results, it was found that postural oscillation was higher in the visual occlusion condition for both groups. Concomitant to this, we conclude that in the challenging condition, where the base of support is reduced, the HIV group presents greater oscillation (medial-lateral) than the non-HIV group.
\end{abstract}

Keywords: postural balance; HIV; motor activity.

\section{RESUMO}

Introdução: Alterações motoras são observadas em pessoas vivendo com HIV/AIDS. Essas alterações podem estar associadas à cronicidade da infecção, uso contínuo da medicação antiretroviral e ou pela presença de comorbidades. Objetivo: $O$ objetivo do presente estudo foi avaliar a oscilação postural de pessoas vivendo com HIV/AIDS assintomáticos em tratamento com terapia antirretroviral altamente ativa. Métodos: Vinte e sete indivíduos, recrutados em um centro de referência em HIV, com idade entre 30 e 40 anos, participaram do estudo, divididos em dois grupos: grupo HIV ( $n=12)$ e grupo não HIV $(n=15)$. Os participantes realizaram uma tarefa experimental, permanecendo em uma plataforma de força em posição estática, em posições de apoio bipodal e semi-tandem, em condições com e sem visão. Resultados: Os resultados demonstraram que a oclusão visual, quando adotada a base bipodal, gerou diferenças significativas na área de oscilação e velocidade média em ambos os grupos. Diferenças também foram observadas na área e velocidade média de ambos os grupos quando a posição semi-tandem foi adotada sem visão. Ao comparar os grupos, foi possível identificar diferenças significativas na base semi-tandem com visão. Conclusão: Considerando esses resultados, constatou-se que a oscilação postural foi maior na condição de oclusão visual para ambos os grupos. Concomitante a isso, concluímos que na condição desafiadora, onde a base de suporte é reduzida, o grupo HIV apresenta maior oscilação (médiolateral) que o grupo não HIV.

Palavras-chave: equilíbrio postural; HIV; atividade motora

Received on: 08/23/2018

Revised on: 02/27/2019

Accepted on: $04 / 05 / 2019$

Corresponding author: Bruno José Frederico Pimenta - Rodovia Celso Garcia Cid, Km 380 - CEP: 86057-970 - Londrina (PR), Brazil. E-mail: jb.frederico@gmail.com Conflict of interests: nothing to declare. 


\section{INTRODUCTION}

The advent of highly active antiretroviral therapy (HAART) has led to an increase in the life expectancy of people living with HIV/AIDS (PLHA) ${ }^{1,2}$. This has meant that PLHA are more exposed to the chronic effects of continued use of medication and infection $^{3-5}$. The present conjuncture causes several alterations in PLHA that can, directly or indirectly, impact on the motor components ${ }^{6,7}$.

Sway has been shown to be sensitive to the effects of continuous exposure to medication ${ }^{7}$. This occurs because prolonged exposure to medication triggers alterations in the metabolic system and Central Nervous System $(\mathrm{CNS})^{6,8-10}$. Changes in these parameters imply in a reduction in muscular strength and efferent neural responses ${ }^{6,7}$.

The fragility that emerges from the progression of infection at more advanced stages is another factor which can provoke changes in sway. In a symptomatic condition (AIDS) the PLHA is vulnerable to the presence of neuropathy and other comorbidities. This condition can, directly or indirectly, influence postural sway, specifically in more difficult tasks ${ }^{11,12}$.

However, the unfolding impacts of HIV and/or HAART on postural sway still do not present consensus ${ }^{11}$. From this perspective, understanding postural sway behavior in PLHA allows prophylaxis strategies to maintain functionality in tasks of daily living ${ }^{11}$. The postural sway of PLHA compared to non-HIV individuals may indicate pathological conditions that are still in an asymptomatic state ${ }^{3,6}$.

Thus, considering the lack of specificity and new nuances of the infection, the objective of the present study was to evaluate the static postural sway of people living with HIV/AIDS under treatment with HAART. It was expected that in light of the new characteristics of the HIV infection, sway in PLHA would be different from that of non-PLHA. Therefore, another hypothesis raised by this study is that the absence of visual information would increase postural instability for both PLHA and non-PLHA.

\section{METHODS}

The participants in the present study (PLHA and non-PLHA) were approached at the Dr. Bruno Piancastelli Filho Reference Center located in Londrina, Paraná, Brazil. The invitation to participate was random and without identification of the participant's serology. This procedure aimed to avoid possible exposure of the individual, since the invitation occurred at the entrance of the pharmacy at the Reference Center.

For this study 324 individuals were invited between July and October in 2015. However, 183 did not agree to participate. The 141 who agreed to participate were taken to a private room where it was verified that they met the inclusion criteria. Of the 141 participants, 61 did not meet some inclusion criterion (aged between
30 and 40 years; having knowledge, through examinations, of serological condition; not using prostheses or orthoses; not abusing alcohol or drugs; and, being in an asymptomatic stage).

Following this triage, 53 individuals were invited to participate in the study and organized a scheduled return. The return was necessary to apply an anamnesis to verify serological condition, time use of HAART, time of infection, age, frequency of falls, and pathologies. In this meeting, the sway was also evaluated through experimental tasks. However, of the 53 individuals only 27 (fourteen males and thirteen females) performed the anamnesis and tasks.

After procedures, the participants were grouped into an HIV group (GHIV) and non-HIV group (GNHIV). Through the anamnesis, both the GHIV and GNHIV participants reported that they rarely suffered falls, although two participants (one from the GHIV and one from the GNHIV) reported having fallen once in the 30 days prior to the anamnesis and tasks. The participants (GHIV and GNHIV) also reported the absence of pathologies, affirming that they were not undergoing any type of treatment, except for HAART in the GHIV.

The GHIV, specifically, was composed of twelve participants, eight men and four women, who had a mean time of diagnosis of HIV infection of eleven years (SD 6.08) and an average time of HAART use of 10.6 years (SD 6.48). The GNHIV was composed of fifteen individuals, nine women and six men, who were not diagnosed with HIV.

In order to establish greater socioeconomic homogeneity, nonHIV participants were also recruited at the Reference Center, emphasizing that their participation was conditional on the same inclusion criteria as people living with HIV, however, they were required to have a negative serological condition. As this research involves humans, all the procedures adopted were in accordance with the ethical precepts of the country.

\section{Experimental Protocol}

The tasks were characterized by the amount of time the participants remained in the bipedal (BP) and semi-tandem (ST) positions on a force platform. During the execution of the tasks, BP and ST positions, the participants adopted an upright and static position, on a force platform, barefoot and with arms placed next to the body.

The BP and ST positions were standardized. In the BP position all individuals kept their feet parallel, shoulder width apart, with their heels separated by a distance of two centimeters and feet open at $30^{\circ}$. In the semi-tandem condition, the feet were parallel to each other, with the right foot positioned half a foot length in front of the left. The position of the feet in both support bases was traced on the force platform by means of adhesive tape, to guarantee the same position for all participants.

The experimental conditions outlined for the study included the support bases bipedal (BP), in the conditions with vision (BPYV) 
and without vision (BPNV), and semi-tandem (ST), with vision (STYV) and without vision (STNV). Three attempts were performed in each experimental condition (BPYV, BPNV, STCV, and STNV), from which the mean was calculated. In this way, three attempts were established in the BPYV, BPNV, STYV, and STNV positions, totaling 12 experimental attempts, previously randomized by a draw for each participant.

The permanence time in each experimental condition (BPYV, BPNV, STYV, and STNV) was 30 seconds, with an interval of one minute between conditions. In the case of disturbances to the individual, internal or external, during the 30 seconds, the attempt was excluded and a retry performed.

In the BPYV and STYV conditions, participants were required to keep their gaze fixed on a circular target positioned on the wall two meters from the force platform. For the BPNV and STNV conditions, the participants were required to wear a blindfold that could be withdrawn at any report of discomfort. Lastly, the participants were allowed one attempt to familiarize themselves with the platform and experimental conditions. Two previously trained researchers were present during the trials to ensure the non-occurrence of falls in cases of large postural oscillation.

\section{Instrument}

The instrument used in the present study was a Bertec Corporation ${ }^{\circledR}$ brand load cell, model 4060-08, size (LxWxH) $60 \mathrm{~cm} \times 40 \mathrm{~cm} \times 5 \mathrm{~cm}$, with a $1000 \mathrm{~Hz}$ sampling frequency and a capacity of $220 \mathrm{Kg}$

The center of pressure (COP) data provided by the platform were exported to Matlab software where they were analyzed using a specific routine, smoothed by means of a $4^{\text {th }}$ order Butterworth low pass filter and a defined cut-off frequency of $5 \mathrm{~Hz}$, through residual analysis.

The variables calculated from the COP provided by the platform were: the area of oscillation $\left(\mathrm{cm}^{2}\right)$ being calculated by means of $95 \%$ of the ellipse, which, in turn, is obtained by means of the dispersion measurements of the COP; the mean amplitude $(\mathrm{cm})$, which refers to the distance between the minimum and maximum displacement in the anterior-posterior and medial-lateral directions of the COP; and the mean velocity $(\mathrm{cm} / \mathrm{s})$, which represents the COP total displacement over time.

\section{Statistical Analysis}

The independent variables under analysis were the groups, GHIV and GNHIV, and the conditions BPYV, BPNV, STYV, and STNV. The dependent variables were the area of oscillation of COP (AR), anterior-posterior (AP) and medial-lateral (ML) amplitude, and mean velocity of COP displacement (VE). The study variables, dependent and independent, were adjusted using log base 10 and the normality and sphericity assumptions were analyzed by the Shapiro-Wilk and Mauchly's tests, respectively.
Given the assumptions, the descriptive analysis of the data are presented as mean and standard deviation. The means of the variables were compared using two-way ANOVA for repeated measures, with the Bonferroni post hoc to indicate possible differences $(\mathrm{p}<.05)$. The effect size in the group factor and conditions with and without vision was calculated by means of the partial Eta squared (partial $\eta^{2}$ ).

The values of anthropometric variables (body weight and height) and age were compared intergroup to ensure homogeneity among the participants. Comparisons were performed using the Mann-Whitney test $(\mathrm{p}<.05)$, and the descriptive statistics are presented as median and interquartile range, since these variables did not present normality. All analysis in the present study were performed using the software SPSS (v.21).

\section{RESULTS}

The participants in the GNHIV were characterized as 36 years $(\mathrm{Q} 1=33, \mathrm{Q} 3=38), 72.4 \mathrm{~kg}(\mathrm{Q} 1=62, \mathrm{Q} 3=80)$, and $1.6 \mathrm{~m}(\mathrm{Q} 1=1.6$, $\mathrm{Q} 3=1.76)$ and the GHIV as 38.5 years $(\mathrm{Q} 1=34.5, \mathrm{Q} 3=40), 74.2 \mathrm{~kg}$ $(\mathrm{Q} 1=63.1, \mathrm{Q} 3=86.5)$, and $1.7 \mathrm{~m}(\mathrm{Q} 1=1.5, \mathrm{Q} 3=1.78)$. There were no differences in the intergroup comparisons of weight $(\mathrm{p}=0.58)$, height ( $p>0.99)$, and age ( $p=0.06)$, confirming the homogeneity of the groups for these parameters.

The results of the descriptive statistical analysis, means and standard deviation, and comparisons between the GHIV and GNHIV for the variables, AR; VE; ML; and AP in the BPYV and BPNV conditions can be observed in Figure 1.

The absence of visual information was responsible for the increase in postural instability for the GHIV in the variables AR $\left(\mathrm{F}=7.60, \mathrm{df}=1, \mathrm{p}=0.011\right.$, partial $\left.\eta^{2}=.233\right), \mathrm{AP}(\mathrm{F}=13.14, \mathrm{df}=1$, $\mathrm{p}=0.001$, partial $\left.\eta^{2}=0.343\right), \mathrm{ML}(\mathrm{F}=4.45, \mathrm{df}=1, \mathrm{p}=0.04$, partial $\left.\eta^{2}=0.151\right)$, and $\operatorname{VE}\left(\mathrm{F}=20.04, \mathrm{df}=1, \mathrm{p}=0.001\right.$, partial $\left.\eta^{2}=0.445\right)$.

On the other hand, in the GNHIV, the difference between the BPYV and BPNV conditions was significant for the variables AR $\left(\mathrm{F}=5.30, \mathrm{df}=1, \mathrm{p}=0.004\right.$, partial $\left.\eta^{2}=0.152\right), \mathrm{AP}(\mathrm{F}=9.82, \mathrm{df}=1$, $\mathrm{p}=0.004$; partial $\left.\eta^{2}=0.282\right)$, and $\mathrm{VE}(\mathrm{F}=24.33, \mathrm{df}=1, \mathrm{p}=0.001$, partial $\eta^{2}=0.493$ ).

In the comparison between BPYV and BPNV, in the GNHIV, the $\mathrm{ML}$ presented no difference $(\mathrm{F}=1.52, \mathrm{df}=1, \mathrm{p}=0.22$, partial $\left.\eta^{2}=0.058\right)$. Through these findings, it was observed that although the ML amplitude was significantly higher in the BPNV condition than in the BPYV condition for the GHIV group, the same was not observed for the GNHIV.

The comparison between the groups, GHIV and GNHIV, did not present significant differences in any of the variables in the conditions BPYV $\left(\mathrm{F}=1.01, \mathrm{df}=1, \mathrm{p}=0.32\right.$, partial $\eta^{2}=0.03$; AP, $\mathrm{F}=0.007, \mathrm{df}=1, \mathrm{p}=0.93$, partial $\eta^{2}=0.001 ; \mathrm{ML}, \mathrm{F}=0.005, \mathrm{df}=1$, $\mathrm{p}=0.94$, partial $\eta^{2}=0.000 ; \mathrm{VE}, \mathrm{F}=0.189, \mathrm{df}=1, \mathrm{p}=0.66$, partial $\left.\eta^{2}=0.007\right)$ or $\mathrm{BPNV}\left(\mathrm{F}=0.186, \mathrm{df}=1, \mathrm{p}=0.67\right.$, partial $\eta^{2}=0.007$ 
AP, $\mathrm{F}=0.45, \mathrm{df}=1, \mathrm{p}=0.50$, partial $\eta^{2}=0.018 ; \mathrm{ML}, \mathrm{F}=0.188, \mathrm{df}=1$, $\mathrm{p}=0.66$, partial $\eta^{2}=0.007 ; \mathrm{VE}, \mathrm{F}=0.031, \mathrm{df}=1, \mathrm{p}=0.86$, partial $\left.\eta^{2}=0.001\right)$. Thus, under these conditions, the sway behavior of both groups is assumed to be similar.

Figure 2 illustrate the results of the descriptive and analytical statistical analysis of the variables - AR; VE; ML; and AP of the GHIV and GNHIV groups under the STYV and STNV conditions.

Visual occlusion also triggered greater instability in the GHIV group when compared to the STYV and STNV conditions. Thus, with visual occlusion, greater and significant values were observed in the AR, AP, ML, and VE $\left(\mathrm{F}=11.91, \mathrm{df}=1, \mathrm{p}=0.002, \eta^{2}=0.323\right.$; $\mathrm{f}=18.94, \mathrm{df}=1, \mathrm{p}=0.001$, partial $\eta^{2}=0.431 ; \mathrm{F}=26.30, \mathrm{df}=1, \mathrm{p}=0.001$, partial $\eta^{2}=0.513 ; \mathrm{F}=25.62, \mathrm{df}=1, \mathrm{p}=0.001$, partial $\eta 2=0.506$ ).

The same impact of visual occlusion was observed in the GNHIV group when comparing the STYV and STNV conditions. In this group the values were greater and significant in all variables when the visual information was removed; $A R(F=16.64$, $\mathrm{df}=1, \mathrm{p}=0.001$, partial $\left.\eta^{2}=0.40\right), \mathrm{AP}(\mathrm{F}=19.48, \mathrm{df}=1, \mathrm{p}=0.001$, partial $\left.\eta^{2}=0.438\right), M L\left(F=23.65, d f=1, p=0.001\right.$, partial $\left.\eta^{2}=0.486\right)$, and $\operatorname{VE}\left(\mathrm{F}=28.92, \mathrm{df}=1, \mathrm{p}=0.001\right.$, partial $\left.\eta^{2}=0.536\right)$.
The comparisons between the GHIV and GNHIV in the STYV condition did not present significant differences in the variables AR $\left(\mathrm{F}=0.002, \mathrm{df}=1, \mathrm{p}=0.96\right.$, partial $\left.\eta^{2}=0.000\right), \operatorname{AP}(\mathrm{F}=.349, \mathrm{df}=1$, $\mathrm{p}=0.56$, partial $\left.\eta^{2}=0.014\right)$, or $\mathrm{VE}(\mathrm{F}=1.18, \mathrm{df}=1, \mathrm{p}=0.28$; partial $\left.\eta^{2}=0.045\right)$. The variable $M L$ presented significant differences $\left(\mathrm{F}=4.40, \mathrm{df}=1, \mathrm{p}=0.04\right.$, partial $\left.\eta^{2}=0.15\right)$, with the GHIV presenting greater amplitude than the GNHIV.

The results of the comparisons between the GHIV and GNHIV in the STNV did not present significant differences for any of the variables, which demonstrates that the disturbance generated by the visual occlusion triggered similar behavior between the groups in the variables $(\mathrm{AR}, \mathrm{F}=0.132, \mathrm{df}=0.1, \mathrm{p}=0.72$ and partial $\eta^{2}=0.005 ;$ AP, $\mathrm{F}=0.000, \mathrm{df}=1, \mathrm{p}=0.98$, partial $\eta^{2}=0.000$; ML, $F=2.95, d f=1, p=0.09$, partial $\eta^{2}=0.106$; VE, $F=0.394, d f=1$, $\mathrm{p}=0.53$, partial $\eta^{2}=0.01$ ).

\section{DISCUSSION}

The objective of the present study was to evaluate the postural sway of people living with HIV/AIDS under treatment with highly active antiretroviral therapy (HAART). Through the

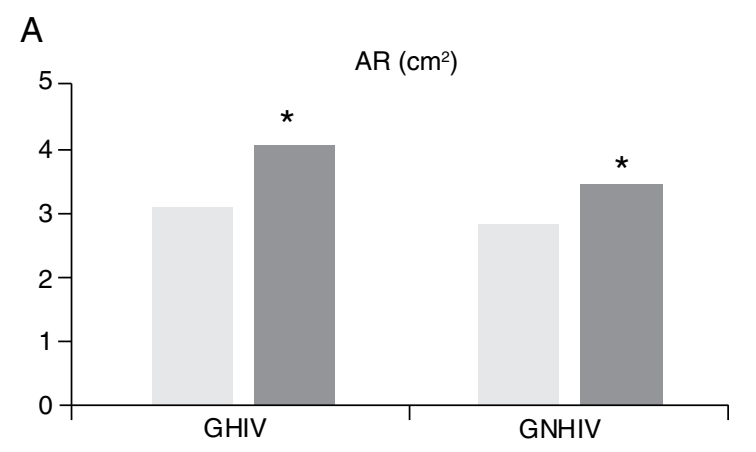

B

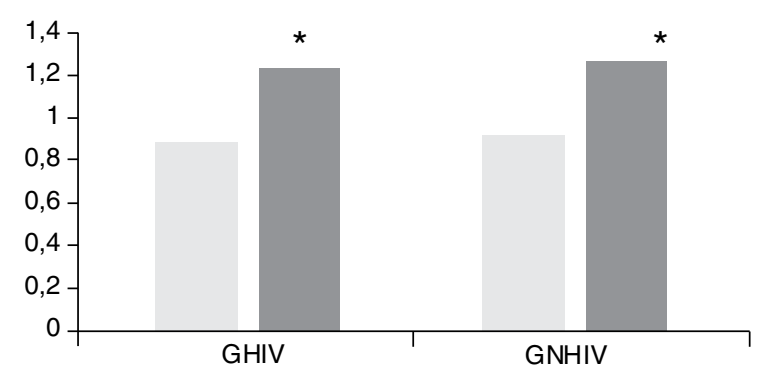

D AP $(\mathrm{cm})$

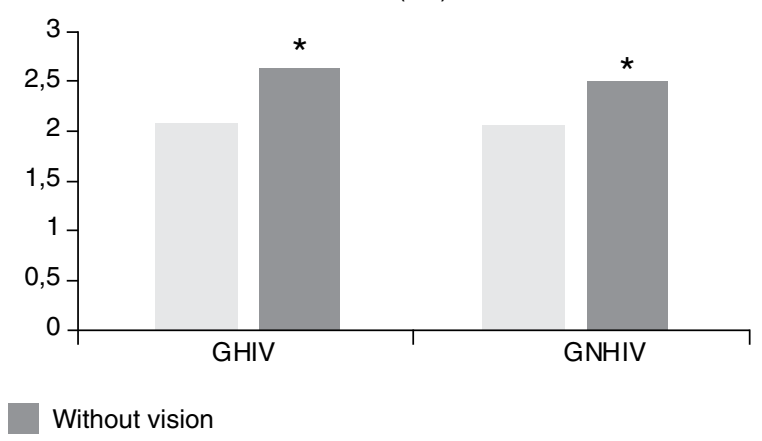

${ }^{*} \mathrm{p}<0.05$ in the intragroup comparison (Two-way ANOVA for repeated measures)

Figure 1: Comparison of the support bases bipedal with vision (BPYV) and without vision (BPNV) conditions for HIV group (GHIV) and nonHIV group (GNHIV). (A) Area of oscillation (AR). (B) mean velocity of center of pressure displacement (VE). (C) Medial-lateral amplitude (ML). (D) Antero-lateral amplitude (AP). 
posturographic analysis, greater medial lateral (ML) amplitude of the PLHA was identified in the STYV than the non-PLHA.

The data also allowed us to identify that visual information is essential for the maintenance of postural sway for both PLHA and non-PLHA. In this context, the hypothesis that the PVHA sway would be different from the non-PLHA was accepted, and that occlusion of visual information is a factor which increases sway in both groups.

Previous studies have identified that the postural sway of PLHA may be compromised by several factors, in addition to being a condition present in asymptomatic individuals ${ }^{11,13-15}$. The scholars ${ }^{6,15}$ have suggested that increased postural oscillation is associated with manifestations of HIV in the central nervous system (CNS). These manifestations tend to affect the subcortical structures and the infratentorial brain system, compromising efferent signals ${ }^{6,15,16}$.

On the other hand, some authors associate HAART with generalized toxicity in the organism ${ }^{8,9}$, stemming from the continued use of HAART and impacting muscle function, the sensory system, and fat distribution ${ }^{8,9}$. This variability in the condition implies in the maintenance of sway ${ }^{10,13,15}$.
The results presented above interact with the present study, since the GHIV presented greater ML amplitude than the GNHIV in the STYV condition. In terms of neural control, a high amplitude of ML demands a proximal-distal muscular response to maintain balance ${ }^{17}$. This response is adjusted by the hip strategy in order to respond to the disturbance generated by a reduction in the support base ${ }^{18}$.

The hip strategy controls sway dependent on the torques generated by the trunk and hip muscles. In this context, the force generated by these muscle groups becomes indispensable for torque to restore or maintain balance ${ }^{19,20}$.

The fact that the difference in intragroup ML amplitude occurs in a condition with visual information available suggests changes in the neuro-muscular control mechanisms ${ }^{17,20}$. This condition can be better understood when considering that the GNHIV did not present differences between BPYV and BPNV.

On the other hand, the GHIV demonstrated a difference in ML amplitude between BPYV and BPNV conditions, a result not observed in the GNHIV. This indicates that the ankle strategy was sufficient only for the GNHIV ${ }^{18,20}$ while the GHIV resorted to the hip strategy.
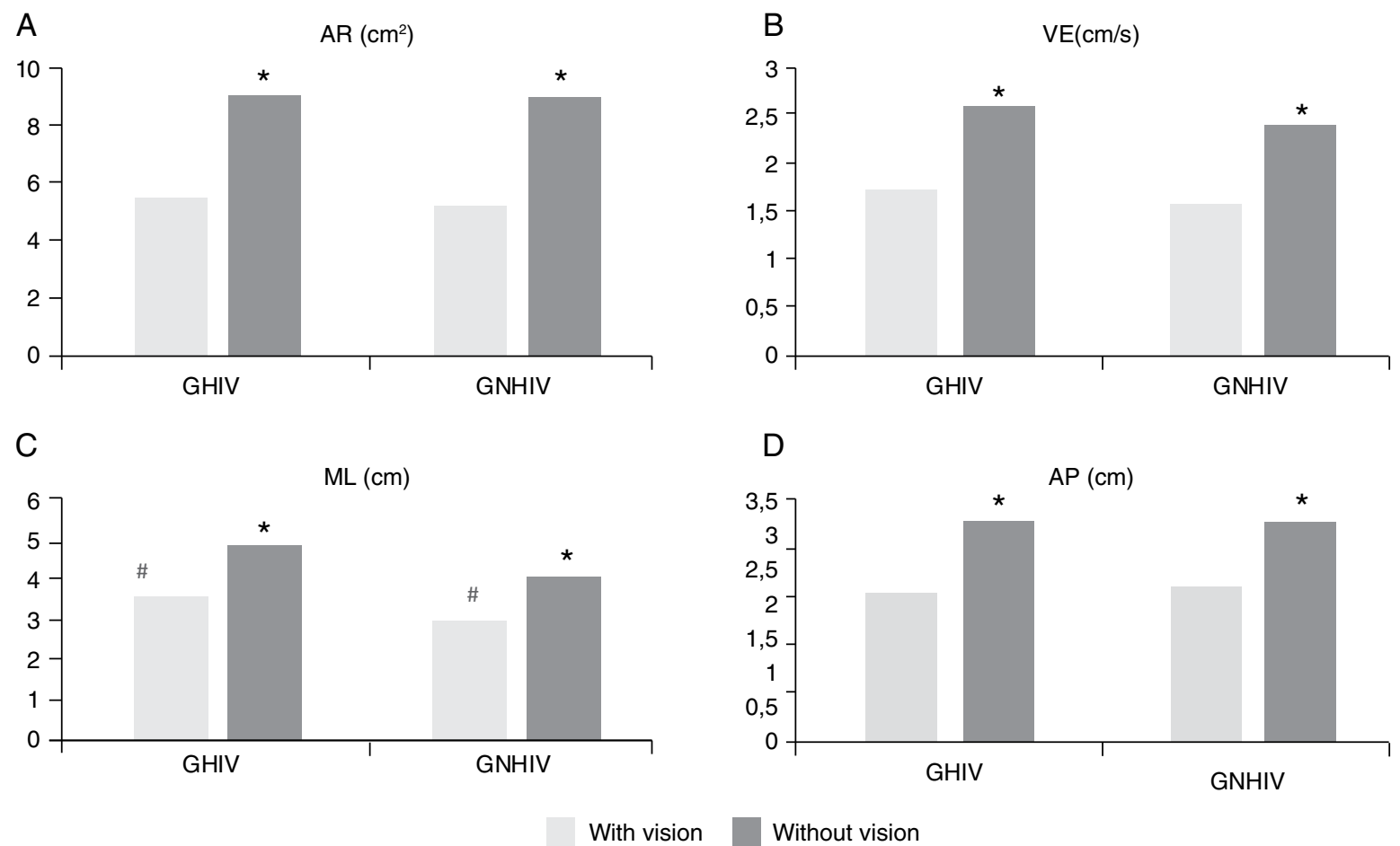

${ }^{*} \mathrm{p}<0.05$ in the intragroup comparison, $\# p<0.05$ in the intergroup comparison (Two-way ANOVA for repeated measures)

Figure 2: Comparison of the semi-tandem with vision (STYV) and without vision (STNV) conditions HIV group (GHIV) and non-HIV group (GNHIV). (A) Area of oscillation (AR). (B) mean velocity of center of pressure displacement (VE). (C) Medial-lateral amplitude (ML). (D) Antero-lateral amplitude (AP). 
Maintenance of balance using a muscular strategy depends initially on the sensory information. Studies ${ }^{21-25}$ indicate that the reduction or manipulation of sensory information results in increased postural sway. This is because the muscular response to disturbances is intrinsically conditioned to the sensory perception ${ }^{20,26}$.

Specifically, the reduction in visual information has been related to the postural sway of several populations ${ }^{27-29}$, this being the most reliable information for humans, as its relevance for the maintenance of balance can reach $50 \%$ in challenging conditions ${ }^{23}$.

The results of the present study showed the importance of visual information for both groups (GHIV and GNHIV). With the occlusion of visual information, there was greater instability in all experimental tasks. In the absence of sensory information, the central nervous system (CNS) has the ability to modulate the participation of sensory channels to maintain balance ${ }^{28,29}$ however, this modulation does not completely compensate for suppression of vision ${ }^{30,31}$.

In summary, the present research accepted the initial hypothesis that postural balance of the GHIV under continuous HAART use differs from GNHIV. Concomitantly, the hypothesis that the absence of visual feedback would generate greater sway in both groups was also accepted.

Some limitations should be considered in order to better understand our results, for example: the sample size, which does not allow our results to be generalized; and the median age of the GHIV, as younger adults could better adapt to the experimental tasks. However, the present study has some significant points such as: intragroup and intergroup homogenization and the sensitivity of the instrument used to evaluate postural sway.

Finally, we believe that these findings are relevant to specialists and non-specialists in this area. The results corroborate with previous research, evidencing the need for better understanding of the changes in balance and impacts on the quality of life in PLHA. For this, we suggest the investigation of the muscular strategies adopted in day-to-day tasks, through electromyography, in addition to the realization of linear regression to map the variables that can impact balance.

\section{REFERENCES}

1. Rossi GMS, Maluf ECP, Carvalho DS, Ribeiro CEL, Battaglin CRP. Impacto da terapia antirretroviral conforme diferentes consensos de tratamento da Aids no Brasil. Rev Panam Salud Publica. 2012;32(2):117-23

2. Szwarcwald CL, Castilho EA. A epidemia de HIV/AIDS no Brasil: três décadas. Cad Saude Publica. 2011:27(1):4-5. http://dx.doi.org/10.1590/S0102-311X2011001300001

3. Saylor D, Dickens AM, Sacktor N, Slusher B, Pletnikov M, Mankowski JL, et al. HIV-associated neurocognitive disorder - pathogenesis and prospects for treatment. Nat Rev Neurol. 2016;12(4):234-48

http://dx.doi.org/10.1038/nrneurol.2016.27

4. Armentano TC, Silva AR, Ferrari LV, Mateus NG, Mello R. A lipodistrofia em pacientes que vivem com HIV/AIDS. Rev Pesqui Cuid Fundam. 2013;5(5):173-81.

http://doi.org/10.9789/2175-5361.2013v5n5esp173

5. Deeks GS, Lewin SR, Havlir DV. The end of AIDS: HIV infection as a chronic disease. Lancet. 2013;382(9903):1525-33. http://dx.doi.org/10.1016/S0140-6736(13)61809-7

6. Tsea W, Cersosimo MG, Gracies JM, Morgello S, Olanow CW, Koller W. Movement disorders and AIDS: a review. Parkinsonism Relat Disord. 2004;10(6):323-34.

http://dx.doi.org/10.1016/j.parkreldis.2004.03.001

7. Richert L, Dehail P, Mercié P, Dauchy FA, Bruyand M, Greib C, et al. High frequency of poor locomotor performance in HIV-infected patients. AIDS. 2011;25(6):797-805.

http://dx.doi.org/10.1097/QAD.0b013e3283455dff

8. Scruggs RE, Naylor AJD. Mechanisms of zidovudineinduced mitochondrial toxicity and myopathy. Pharmacology. 2008;82(2):83-8

http://dx.doi.org/10.1159/000134943

9. Moyle G. Clinical manifestations and management of antiretroviral nucleoside analog-related mitochondrial toxicity. Clin Ther. 2000;22(8):911-36

http://dx.doi.org/10.1016/S0149-2918(00)80064-8
10. Bauer LO, Wu Z, Wolfson LI. An obese body mass increases the adverse effects of HIV/AIDS on balance and gait. Phys Ther. 2011;91(7):1063-71

http://dx.doi.org/10.2522/ptj.20100292

11. Berner K, Morris L, Baumeister J, Low Q. Objective impairments of gait and balance in adults living with HIV-1 infection: a systematic review and meta-analysis of observational studies. BMC Musculoskeletal Disorders. 2017;18(325):2-26.

http://doi.org/10.1186/s12891-017-1682-2

12. Galantino ML, Eke-Okoro ST, McGinnis $P Q$, Flatley K. Exploration of balance difficulties in aids neuropathy. Rehab Oncol. 2002;20(2):6-12.

https://dx.doi.org/10.1097/01893697-200220020-00006

13. Bauer LO, Ceballos NA, Shanley JD, Wolfson LI. Sensorimotor dysfunction in HIV/AIDS: effects of antiretroviral treatment and comorbid psychiatric disorders. AIDS. 2005;19(5): 495-502.

https://doi.org/10.1097/01.aids.0000162338.66180.0b

14. Zhou Y, Li R, Wang X, Miao H, Wei Y, Ali R, et al. Motor-related brain abnormalities in HIV-infected patients: a multimodal MRI study. Neuroradiology. 2017;59(11):1133-42. http://doi.org/10.1007/s00234-017-1912-1

15. Erlandson KM, Allshouse AA, Jankowski CM, Duong S, MaWhitney $\mathrm{S}$, Kohrt WM, et al. Risk factors for falls in HIV-infected persons. J Acquir Immune Defic Syndr. 2013:61(4):484-9. http://doi.org/10.1097/QAI.0b013e3182716e38

16. Sullivan VE, Rosenbloom MJ, Rohlfing T, Kemper CA, Deresinski S, Pfefferbaum A. Pontocerebellar contribution to postural instability and psychomotor slowing in HIV infection without dementia. Brain Imaging Behav. 2011;5(1):12-24. http://doi.org/10.1007/s11682-010-9107-y

17. Suzuki Y, Nomura T, Casadio M, Morasso P. Intermittent controle with ankle, hip, and mixed strategies during quiet standing: a theoical proposal basead on a double inverted pensulum model. J Theor Biol. 2012:310:55-79. https://doi.org/10.1016/j.jtbi.2012.06.019 
18. Sousa AS, Silva A, Tavares JM. Biomechanical and neurophysiological mechanisms related to postural control and efficiency of movement: a review. J Somatosens Mot Res. 2012;29(4):131-43.

https://doi.org/10.3109/08990220.2012.725680

19. Dias RBM, Wibelinger LM. Correlação entre força muscular (torque muscular) de flexores e extensors de joelho e risco de quedasemidosos. Rev Bras Cienc Env Hum. 2010;7(Suppl 1):135-43.

https://doi.org/10.5335/rbceh.2012.984

20. Baston C, Mancini M, Schoneburg B, Horak F, Rocchi L. Postural strategies assessed with inertial sensors in health and parkinsonian subjects. Gait Posture. 2014;40(1):70-5. https://doi.org/10.1016/j.gaitpost.2014.02.012

21. Mochizuki L, Amadio AC. As funções do controle postural durante a postura ereta. Fisioter Pesqui. 2003;10(1):7-15. https://doi.org/10.1590/fpusp.v10i1.77416

22. Bonfim TR, Barela JA. Efeito da manipulação da informação sensorial na propriocepção e no controle postural. Fisioter Mov. 2007;20(2):107-17.

23. Cohen HS, Cox C, Springer G, Hoffman HJ, Young MA, Margolick $\mathrm{JB}$, et al. Prevalence of abnormalities in vestibular function and balance among HIV-Seropositive and HIV-Seronegative women and men. PLoS One. 2012;7(5):e38419. https://doi.org/10.1371/journal.pone.0038419

24. Soares AV. A contribuição visual para o controle postural. Rev Neurocienc. 2010;18(3):370-9.
25. Kleiner AFR, Schlittler DXC, Sánchez-Arias MDR. O papel dos sistemas visual, vestibular, somatosensorial e auditivo para o controle postural. Rev Neurocienc. 2011;19(2):349-57.

26. Gusmão MFS, Reis LA. Efeito do treinamento sensório-motor no equilíbrio idosos: revisão sistemática. Rev Saúde Coletiva UEFS. 2017;7(1):64-70.

http://dx.doi.org/10.13102/rscdauefs.v7i1.1056

27. Man L, Kleinpaul JF, Teixeira CS, Mota CB. Influência dos sistemas sensoriais na manutenção do equilíbrio em gestantes. Fisioter Mov. 2011;24(2):315-25.

http://dx.doi.org/10.1590/S0103-51502011000200013

28. Toledo DR, Rinaldi NM, Barela JA. Controle postural em crianças: efeito da manipulação da informação visual discreta. Braz J Motor Behav. 2006;1(1):82-8.

29. Barela JA, Polastri PF, Freitas Junior PB, Godoi D. Efeito da exposição visual no acoplamento entre informação visual e controle postural em bebês. Rev Paul Educ Fís. 2003;17(1):16-31. https://doi.org/10.11606/issn.2594-5904.rpef.2003.138838

30. Schmid M, Nardone A, Nunzio AM, Schmid M, Schieppati M Equilibrium during static and dynamic tasks in blind subjects: no evidence of cross-modal plasticity. Brain. 2007;130(Pt 8):2097107

http://dx.doi.org/10.1093/brain/awm157

31. Tomomitsu MSV, Alonso AC, Morimoto E, Bobbio TG, Greve JMD Static and dynamic postural control in low-vision and normalvision adults. Clinics. 2013;68(4):517-21. http://dx.doi.org/10.6061/clinics/2013(04)13 